УДК 378:81 - 13(045)

DOI:

Ірина Западинська, кандидат педагогічних наук, доцент кафедри іноземної філології та перекладу Вінницького торговельно-економічного інституту Київського національного торговельно-економічного університету

\title{
САМООСВІТА ВИКЛАДАЧА ІНОЗЕМНИХ МОВ В УМОВАХ ІНФОРМАТИЗАЦЇ̈ СУЧАСНОГО СУСПІЛЬСТВА
}

У статті зазначено, щзо інформатизація всіх сфер суспільного життя впливає на функиії освіти в иілому і методичну роботу сучасного викладача зокрема. Зазначено на зростання ролі самоосвітньої діяльності педагога. Визначено напрямки самоосвітньої діяльності викладача іноземних мов (вивчення нових навчальних програм, підручників та навчальних посібників, вивчення передового педагогічного досвіду; оволодіння технічних засобів навчання і т.д.). Охарактеризовані види самоосвітньої діяльності. Визначено принции методичної роботи з науково-педагогічним складом та вказано специфіку їх обліку в процесі самоосвіти. Вказано на основні етапи самоосвітньої діяльності педагога (діагностичний, ијільової, організаційний, діяльнісний, підсумковий).

Ключові слова: самоосвіта; напрямки; види та принципи самоосвітньої діяльності; методична робота; інформаційне суспільство; інформатизаиія; викладач іноземних мов.

Jim. 9.

Iryna Zapadynska, Ph.D.(Pedagogy), Associate Professor of the Foreign Philology and Translation Department Vinnytsya Trade and Economic Institute Kyiv National University of Trade and Economics

\section{THE SELF-EDUCATION OF PEDAGOGICAL WORKER OF FOREIGN LANGUAGE IN THE CONDITIONS OF INFORMATION OF MODERN SOCIETY}

The article states that the computerization of all spheres of public life affects the function of education in general and the methodical work of the modern pedagogical worker in particular. The article indicates the growing role of self-educational activity of pedagogical worker. The article deals with the directions of self-activity of the foreign language pedagogic (the study of new curricula, textbooks and teaching aids, learning the advanced pedagogical experience, mastery of technical training, etc.). The author characterizes the kinds of self-educational activity and the principles of methodical work with teachers as well as the specifics of their account in the process of self-education. The article indicates the main stages of self-educational activity of the pedagogical worker (diagnostic, target, organization, activity, final).

Modern society has entered a qualitatively new stage of development, when the main products of production are knowledge and information. The main features of the modern world were an increase in the role of information in the life of man and society, the growth of the number of information communications, as well as the creation of a global information space. We are talking about the creation of an information society, which put forward the task of transition from reproductive to creative civilization. In connection with this, the functions of education also change. Today, before this social institute, the following target functions are: - the transition from the translation of the experience of previous generations to ensuring survival on the natural, social and spiritual levels; - transformation of education into the share of human life, when the content of continuous education directly determines the nature of human needs (not the needs are met as a result of education, and education determines the needs); - the transformation of education into the means of selection of mankind on social, national, intellectual and other grounds, as well as a means for the unification of peoples on the general principles of being. New information in the modern world appears lightning fast, but just as quickly becomes irrelevant. In such circumstances, the issue of training a specialist in professional activities is complicated, since in the course of several years after the completion of a higher education institution, the knowledge gained by him appears to be irrelevant, incomplete, and sometimes outdated. This problem does not lose its weight when it comes to the teacher, because for him, as well as for any other specialist, the ability to search for useful, relevant information, analyze and comprehend, translate information into knowledge, apply knowledge in time to practice, freely exchange and distribute them in a professional society. In view of this, in the process of increasing the professional skills of the teacher, a methodological work that plays a major role in the process of raising the professional skill of the teacher, whose main tasks include: -familiarization with the achievements of psychological and pedagogical science with the aim of raising the professional level; study of advanced pedagogical experience and its dissemination; - improvement of professional skills of the teacher, 


\section{САМООСВТТА ВИКЛАДАЧА ІНОЗЕМНИХ МОВ В УМОВАХ ІНФОРМАТИЗАЦІЇСУЧАСНОГОСУСПІЛЬСТВА}

in particular by mastering the most rigorous methods of teaching and educating students; exchange of experience between members of the teaching staff, etc.

Keywords: self education; directions; kinds and principles of self-educational activity; methodical work; information society; informatization; foreign language pedagogical worker.

П остановка проблеми. Сучасне суспільство вступило у якісно новий етап розвитку, коли головними продуктами виробництва стають знання та інформація. Основними рисами сучасного світу стало збільшення ролі інформації в житті людини і суспільства, зростання кількості інформаційних комунікацій, а також створення глобального інформаційного простору. Говоримо про створення інформаційного суспільства, яке висунуло завдання переходу від репродуктивної до креативної цивілізації.

У зв'язку з цим змінюються й функції освіти. Сьогодні перед цим суспільним інститутом стоять такі цільові функції: - перехід від трансляції досвіду попередніх поколінь до забезпечення виживання на природному, соціальному та духовному рівнях; - перетворення освіти в частку життєдіяльності людини, коли зміст безперервної освіти напряму визначає характер людських потреб (не потреби задовольняються в результаті одержання освіти, а освіта визначає потреби); - перетворення освіти в засіб селекції людства за соціальною, національною, інтелектуальною та іншими ознаками, а також засіб об'єднання народів на загальних принципах буття [2, 52]. Нова інформація в сучасному світі з'являється блискавично, але так само швидко стає неактуальною. У таких умовах ускладнюються питання підготовки фахівця до професійної діяльності, адже вже за кілька років після завершення вищого навчального закладу отримані ним знання виявляються неактуальними, неповними, а іноді й застарілими. Означена проблема не втрачає своєї ваги, коли мова йде про педагога, адже для нього, як і для будь-якого іншого спеціаліста, важливим стає уміння здійснювати пошук корисної, актуальної інформації, iï аналізувати та осмислювати, переводити інформацію в знання, своєчасно застосовувати знання на практиці, вільно обмінюватися ними та розповсюджувати у професійному товаристві [9]. 3 огляду на це, у процесі підвищення професійної майстерності педагога вагому роль відіграє методична робота, до основних завдань якої належать: - ознайомлення 3 досягненнями психолого-педагогічної науки 3 метою підвищення професійного рівня; - вивчення передового педагогічного досвіду та його поширення; - підвищення професійної майстерності викладача, зокрема шляхом засвоєння найраціональніших методів навчання $\mathrm{i}$ виховання студентів; обміну досвідом між членами педагогічного колективу тощо [6, 307].

Аналіз ступеня дослідження проблеми. Проблеми інформатизації освіти відображено у публікаціях В. Кременя, В. Мудрака, А. Пилипчака, Є. Пінчука та ін. Зокрема, Є. Пінчук зазначає, що процеси інформатизації відкривають широкий доступ до освіти широких мас населення, а відтак держава втрачає монополію на знання і розвиток освіти. Сама ж інформація стає чинником, що інтегрує соціальні, технологічні, економічні, політичні та культурні механізми [7, 10]. Процеси інформатизації забезпечують можливість навчання впродовж життя. Теорія неперервної освіти отримала розвиток упрацях А. Даринського, Н. Ничкало, С. Сисоєвої та ін. Удосконалення методичної компетентності педагога у своїх працях розглядали І. Зязюн, Л. Кондрашова, А. Кузьмінський, В. Олійник, В. Сластьонін, T. Сорочан та ін. Самоосвіті викладача як важливому засобу і умові забезпечення безперервної методичної підготовки педагога присвятили дослідження М. Поташник, Н. Протасова, О. Романовський, В. Сагуйченко, В. Сластьонін та ін.

Мета статті полягає в аналізі самоосвітньої діяльності викладача іноземних мов як форми методичної роботи в умовах інформатизації усіх сфер суспільного життя.

Виклад основного матеріалу. Методична робота в навчально-виховних закладах - це частина системи неперервної освіти педагогів, зміст якої визначається актуальними проблемами освіти та завданнями школи. Організаційні форми методичної роботи у закладах вищої освіти характеризуються багатоманітністю. Зазвичай їх представляють у вигляді трьох взаємопов'язаних груп: масові, групові та індивідуальні форми. До першої групи належать семінари, науковопрактичні конференції, практикуми тощо. До другої - методичні об’єднання, творчі мікрогрупи викладачів тощо. Третя - представлена наставництвом, роботою над особистою творчою темою, стажуванням та самоосвітою.

3. Онишків розподіляє форми методичної роботи на дві групи. До індивідуальних форм автор відносить самоосвіту, стажування, наставництво, індивідуальні консультації. Колективними формами методичної роботи вважає шкільні (міжшкільні), районні (міські) методичні 


\section{САМООСВІТА ВИКЛАДАЧА ІНОЗЕМНИХ МОВ В УМОВАХ ІНФОРМАТИЗАЦІЇСУЧАСНОГО СУСПІЛЬСТВА}

об'єднання учителів, вихователів, класних керівників; районні (міські) методоб'єднання вчителів; постійно діючі та епізодичні семінари для вчителів, вихователів, директорів навчальновиховних закладів, їх заступників; педагогічні читання, виставки, конференції; опорні школи; школи передового педагогічного досвіду; творчі групи та ін. [5, $27-28]$.

В умовах швидкого збільшення інформації, стрімкого поповнення методики навчання новими знаннями та розробками сьогодні надзвичайно зростає вага самоосвіти. Самоосвіта - це освіта, що здобувається у процесі самостійної роботи, без проходження систематичного курсу в навчальному закладі $[6,511]$. В “Українському педагогічному словнику” натрапляємо на таке визначення цього поняття: це “...самостійна освіта, отримання системних знань у певній галузі науки, техніки, культури, політичного життя та ін., яка передбачає безпосередній інтерес особистості в органічному поєднанні із самостійною у вивченні матеріалу" [1, 143]. Самоосвіта викладача - це основна форма підвищення його професійної кваліфікації, що полягає в удосконаленні знань і узагальненні педагогічного досвіду шляхом цілеспрямованої самостійної роботи над літературою і матеріалами, зосередженими в методичному кабінеті, бібліотеці чи мережі Інтернет тощо. Надзвичайно важливою $\epsilon$ самоосвіта для викладачів іноземних мов, адже він має бути готовим до здійснення креативної діяльності, застосування нових технологій навчання в ситуації актуалізації формування іншомовних комунікативних компетенцій особистості.

Важливими напрямами самоосвітньої діяльності викладача іноземних мов є вивчення нових навчальних програм, підручників та навчальних посібників, з' ясування їх особливостей і вимог; вивчення додаткового матеріалу; здійснення самостійної роботи з розв'язування задач, проведення лабораторних і практичних робіт, дослідів і вправ; вивчення передового педагогічного досвіду; опанування технічних засобів навчання.

У галузі методики варто особливу увагу приділити прийомам диференційованого навчання, інтелектуальної діяльності студента, розвитку його самостійності, практичних навичок і встановлення зв'язку урочних та позаурочних занять зі свого предмета [6, 511]. Звертаючи увагу на саме професійну самоосвіту, О. Романовський переконаний, що це сукупність чотирьох видів самоосвітньої діяльності: - фонової загальноосвітньої самоосвіти як самостійної пізнавальної діяльності, яка не вимагає спеціальної організації і планування (читання художньої літератури і періодики, перегляд телепередач, відвідини музеїв, виставок, театрів, участь в екскурсіях тощо); - фонової педагогічної самоосвіти, що охоплює регулярне ознайомлення 3 педагогічною періодикою та науковою й методичною літературою з педагогіки, психології, створення особистої бібліотеки, ії систематизація, накопичення і класифікація різних матеріалів; - перспективної професійної самоосвіти (робота над певною психолого-педагогічною чи методичною проблемою, розрахована на тривалий термін); - актуальної педагогічної самоосвіти як роботи над окремими найістотнішими особистими труднощами у професійній діяльності $[8,15]$. Самоосвіта як форма методичної роботи вчителя іноземних мов виконує низку функцій. Так, Н. Морева [4] виділяє такі: - екстенсивну, що передбачає набуття та накопичення нових знань; - орієнтувальну, спрямовану на визначення себе в культурі та свого місця в суспільстві; - компенсаторну як подоланнянедоліків навчання, ліквідацію прогалин в освіті; - саморозвивальну, що полягає в удосконаленні суб'єктивної картини світу, свідомості, мисленнєвих процесів; - методологічну, покликану долати професійну обмеженість, добудовувати картину світу; - комунікативну, спрямовану на встановлення зв' язків між науками, професіями тощо; - спів творчу як наповнення роботи творчістю; - омолоджуючу, що полягає в доланні інерції мислення, попередження застою в громадській позиції; - психотерапевтичну, спрямовану на збереження повноти буття, почуття причетності до широкого фронту інтелектуального руху людини.

У процесі здійснення самоосвітньої діяльності варто враховувати принципи методичної роботи [3], до яких належать такі: - зв'язок з життям. Безперечно, глобальні проблеми людства впливають на формулювання цілей освітньої практики. Проте самоосвітня діяльність повинна охоплювати також проблеми, близькі для колективу педагогів, або ж самого педагога; - науковість. Аналіз освітньої практики має здійснюватися на високому науковому рівні. Педагог має прагнути до вивчення новітньої наукової та науково-методичної літератури, в якій відображений сучасний стан розвитку педагогічної науки; - системність, що вимагає підходу до методичної роботи загалом і самоосвіти педагога, зокрема, як до цілісної системи, оптимальність якої залежить від єдності мети, завдань, змісту, форм і методів роботи, від спрямованості на кінцевий результат; -комплексний 


\section{САМООСВІТА ВИКЛАДАЧАІНОЗЕМНИХ МОВ В УМОВАХ ІНФОРМАТИЗАЦІЇ СУЧАСНОГО СУСППЛЬСТВА}

характер, що передбачає єдність всіх сторін самоосвіти (питань методики навчання, дидактики і теорії виховання, психології та фізіології, педагогічної етики тощо); - систематичність, послідовність та безперервність, адже самоосвіта $€$ частиною системи безперервної освіти; - творчий характер самоосвітньої діяльності, адже лише за таких умов відбувається дієве стимулювання творчих пошуків педагогів; - конкретність, що означає врахування особливостей конкретної школи та вчителя; - єдність теорії та практики, що передбачає не лише опанування теоретичного матеріалу, але й впровадження його у практичну діяльність кожного педагога, привнесення в неї елементів новизни; - оперативність, гнучкість, мобільність, за яких кожен педагог має бути готовим оперативно реагувати на проблеми й труднощі, що виникають упрофесійній діяльності, та змінювати вектор пошуків на їхнє розв'язання.

На ефективність самоосвітньої діяльності викладача іноземних мов впливають рівень його підготовки, мета самоудосконалення, форми i методи самоосвітньої діяльності тощо. Впровадження самоосвітньої діяльності проходить такі основні етапи: - діагностичний: діагностика рівня предметної, психологопедагогічної, методичної підготовки педагога; діагностика труднощів, з якими стикається викладач у професійній діяльності; - цільовий: постановка мети самоосвітньої діяльності і на цій основі виокремлення їі часткових завдань; - організаційний: відбір та аналіз джерел інформації, участь в колективних формах методичної роботи; - діяльнісний: застосування на практиці отриманих знань, моніторинг та корекція діяльності; - підсумковий: самооцінка процесу та результатів роботи, формулювання власних висновків, проектування перспектив подальшої самоосвітньої діяльності. Може скластися враження, що основне завдання самоосвіти викладача - набуття нової інформації загальноосвітнього чи методичного характеру. Проте в умовах стрімкої інформатизації кількість нових знань та інформації невпинно зростає. Засвоїти її повною мірою уже неможливо. Та і не потрібно. Набагато важливіше навчитися інформацію застосовувати на практиці, сформувавши необхідні компетенції. Зокрема I. Шмиголь виділяє такі можливі компоненти структури професійної компетентності педагога: - мотиваційний - для того щоб на високому рівні виконувати свої професійні обов'язки, педагог повинен бути зацікавлений у своїй діяльності; - спеціально-предметний - формування знань, вмінь, навичок, досвіду із спеціальних дисциплін;
- психолого-педагогічний - характеризує рівень підготовки педагога 3 дисциплін психологопедагогічного циклу, тобто його знання, уміння, навички й досвід 3 педагогіки та психології; методичний або дидактичний - полягає в оволодінні педагогом системою наукових психолого-педагогічних та предметних вмінь і навичок, які грунтуються на знанні засобів, шляхів, умов, форм, методів й прийомів педагогічних впливів та їх ефективному використанні у навчально-виховному процесі; - особистісний характеризується набуттям майбутнім педагогом цілого набору особистісних якостей, які обов'язково мають бути притаманні професійнокомпетентному педагогу: чесність, людяність, терпимість, порядність, чуйність, доброзичливість, відповідальність та інші; - комунікативний вміння педагога спілкуватись, співпрацювати 3 учнями, їх батьками, колегами; - експериментальнодослідницький - вміння та навички підбирати необхідні методики, проводити відповідні експериментальні дослідження та робити аргументовані висновки на основі отриманих результатів, тобто вміння аналізувати та оцінювати; - рефлективність та самостійність самоосвіта, самоаналіз, самомотивація, самооцінка, самокритичність тощо [10, 202].

На їхнє формування має бути спрямована й самоосвітня діяльність педагога. Окрім цього, важливим аспектом самоосвітньої діяльності викладача іноземних мов має стати формування професійно-ціннісних орієнтацій як орієнтирів його соціальної та професійної активності. Засвоєні ним ціннісні орієнтації втілюватимуться у професійній діяльності, визначаючи як їі зміст, так і способи досягнення професійних цілей, полегшуватимуть педагогові залучення школярів до діалогу культур. Саме тому засвоєні викладачем професійноціннісні орієнтації мають носити гуманістичний характер та відображати поціновувати людством в усі віки гуманні ідеали.

Висновки. Отже, самоосвітня діяльність викладача іноземних мов як одна 3 форм методичної роботи забезпечує реалізацію ідеї неперервної освіти із врахуванням вимог суспільства, які постійно змінюються. Це не тільки і не стільки засвоєння нової інформації, скільки формування необхідних компетенцій, творчих якостей особистостей та гуманних ціннісних настанов.

\section{ЛІТЕРАТУРА}

1. Гончаренко С.У. Український педагогічний словник. Київ, 1997.376 с.

2. Комарова О.А. Освіта у вимірі інформаційного 
суспільства. Економічний часопис XXI. 2011. №7 - 8. C. $50-53$.

3. Моисеев А.М., Моисеев О.М. Заместитель директора школы по научной работе. Москва, 1996. $143 \mathrm{c}$.

4. Морева Н.А. Основы педагогического мастерства: учеб. пособие для вузов. Москва, 2006. $320 \mathrm{c}$.

5. Онишків 3.М. Основи школознавства. Тернопіль, 2003. $176 \mathrm{c.}$

6. Педагогика: Большая современная энциклопедия / Сост. Е.С. Рапацевич. Минск, 2005. 720 с.

7. Пінчук Є.А. Модернізація Української системи освіти як теоретико-філософська i практична проблема: автореф. дис. на здобуття наук. ступеня д-ра філос. наук: 09.00.10; Інт вищ. Освіти НАПН України. Київ, 2010. 25 с.

8. Романовський О.Г. Самовдосконалення та самоосвіта як показники рівня професіоналізму. Проблеми та перспективи формування національної гуманітарно-технічної еліти: зб. наук. пр. Вип. 26 (30) / [ред. кол.: В.Г. Кремень (голова) та ін.] ; за ред. Л.Л. Товажнянського, О.Г. Романовського. Харків, 2010.С. $11-18$.

9. Сагуйченко В.В. Самоосвіта в інформаційному суспільстві. Вісник Харківського національного педагогічного університету імені Г.С. Сковороди. Філософія. 2012. Вип. 38. С. 90 - 101.

10. Шмиголь I. Сутність та структура професійної компетентності педагога. Проблеми підготовки сучасного вчителя. 2011. № 11 (Ч. 1). C. $197-204$.

\section{REFERENCES}

1. Goncharenko, S. U. (1997). Ukrainskiy pedagogichniy slovnik [Ukrainian Pedagogical Dictionary]. Kyiv, 376 p. [in Ukrainian].

2. Komarova, O.A. (2011). Osvita u vimiri
Informatsiynogo suspilstva [Education in the dimension of the information society]. Economic magazine XXI. No. 7 - 8, pp. 50 - 53. [in Ukrainian].

3. Moiseev, A.M. (1996). Zamestitel direktora shkolyi po nauchnoy rabote [Deputy Director of the School for Scientific Work]. Moscow, 143 p. [in Russian].

4. Moreva, N.A. (2006). Osnovyi pedagogicheskogo masterstva: ucheb. posobie dlya vuzov [Fundamentals of pedagogical skills: a textbook for universities]. Moscow, 320 p. [in Russian].

5. Onishkiv, Z.M. (2003). Osnovy shkoloznavstva [Fundamentals of School Studies]. Educational book, $176 \mathrm{p}$.

6. Rapatsevich, E.S. (Ed.). (2005). Pedagogika: Bolshaya sovremennaya entsiklopediya [Great modern encyclopedia]. Minsk,720 p. [in Russian].

7. Pinchuk, E.A. (2010). Modernizatsiya Ukrayinskoyi sistemi osviti yak teoretiko-filosofska i praktichna problema [Modernization of the Ukrainian system of education as a theoretical-philosophical and practical problem]. Extended abstract of Doctor's thesis.Institute of Higher Education of the National Academy of Sciences of Ukraine. 25 p. [in Ukrainian].

8. Romanovskiy, O.G. (2010). Samovdoskonalennya ta samoosvita yak pokazniki rivnya profesionalizmu [Self-improvement and self-education as indicators of professionalism]. Problems and prospects of formation of the national humanitarian and technical elite. Vol.26 (30), pp.11 - 18. [in Ukrainian].

9. Saguychenko, V.V. (2011). Samoosvita v Informatsiynomu suspilstvi [Self-education in the information society]. Herald of the Kharkiv National Pedagogical University named after GS Skovorody Philosophy.No.11 (part 1), pp.197 - 204. [in Ukrainian].

Стаття надійшла до редакції 04.06.2019

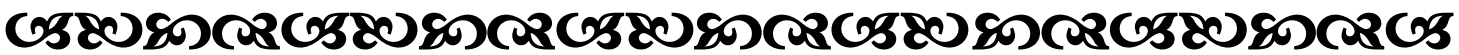

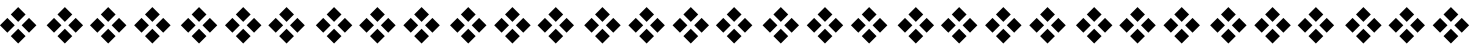

"Фовго сам учись, якщо хочеш навчати інших".

\author{
Тригорій Сқоворода \\ український ббілособ $і$ поет
}

"Кожна людина мене в чомусь перевериує; $і$ в иьому сенсі мені є чому в нъого повчитися".

Ральб Емерсон американський бінособб

\section{$\% * 4 \%$

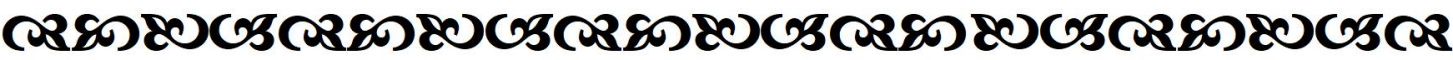

